\title{
СИНТЕЗ И АНАЛИЗ ЗАПАХОВ МОНО- И ДИАЛКОКСИБЕНЗАЛЬДЕГИДОВ
}

\author{
() Е.А. Дикусар ${ }^{I^{*}}$, В.И. Поткин ${ }^{1}$, С.К. Петкевич ${ }^{1}$, М.Ю. Мурашева ${ }^{2}$, С.Г. Стёпин ${ }^{3}$, О.Г. Вьклазов \\ B.A. Чуйко \\ ${ }^{1}$ Институт фризико-органической химии Национальной академии наук \\ Беларуси, ул. Сурганова, 13, Минск, 220072, (Республика Беларусь), \\ e-mail:dikusar@ifoch.bas-net.by \\ ${ }^{2}$ Беларуский государственный университет, пр. Независимости, 4, Минск, \\ 220030 (Республика Беларусь) \\ ${ }^{3}$ Витебский государственный технологический университет, Московский пр., \\ 72, Витебск, 210035 (Республика Беларусь) \\ ${ }^{4}$ ООО «Тереза-Интер», Олимпийский пр., 22, Москва, 129110 (Россия)
}

\begin{abstract}
Разработан удобный и масштабируемый технологический способ получения моно- и диалкоксибензальдегидов - производных природных альдегидофенолов, их аналогов и гомологов с целью их дальнейшего использования в качестве душистых соединений и исходных веществ для последующих химических модификаций и превращений.

Ключевые слова: бензальдегиды ванилинового ряда, фенолы, бромалкилы, реакция Вильямсона, анализ запахов, душистые соединения.
\end{abstract}

\section{Введение}

Гидроксибензальдегиды ванилинового ряда широко используются в пищевой и парфюмерной промышленности в качестве душистых веществ и отдушек [1-3]. Сам ванилин, легко получаемый как из растительного сырья, так и отходов целлюлозно-бумажной промышленности (лигнина или сульфолигнина) [4-7], а также его гомологи и аналоги: ванилаль, изованилин, ортованилин, 4-гидроксибензальдегид и другие альдегидофенолы [8-17], благодаря присутствию в их молекулах гидроксильной и альдегидной групп могут служить удобными и доступными исходными соединениями (или синтонами) для синтеза на их основе целого ряда новых химических веществ, обладающих комплексом ценных и полезных свойств [1-7].

\section{Обсуждение результатов}

Дикусар Евгений Анатольевич - старший научный сотрудник, кандидат химических наук, e-mail: dikusar@ifoch.bas-net.by

Поткин Владимир Иванович - заведующий отделом органической химии, член-корр. НАН Беларуси, доктор химических наук, профессор,

e-mail:potkin@ifoch.bas-net.by

Петкевич Сергей Константинович - научный сотрудник

Мурашова Мария Юрьевна - студентка

Степин Святослав Генрихович - доцент кафедры

химии, кандидат химических наук,

e-mail: stepins@tut.by

Выглазов Олег Генадьевич - главный технологпарфюмер, кандидат химических наук

Чуйко Вера Андреевна - технолог-парфюмер, кандидат химических наук
Цель данной работы - разработка удобного и масштабируемого технологического метода получения моно- и диалкоксибензальдегидов (Іб, ІІб-д, ІІІб, в, ІVб-г, Vб, в, VІб-н, VІІб-м, VІІІб, в) с целью их дальнейшего использования в качестве душистых соединений и исходных веществ для последующих химических модификаций и превращений [2-7]. В качестве исходных альдегидофенолов были использованы салициловый альдегид (2-гидроксибензальдегид) (Іа), 4-гидроксибензальдегид (Iб), opтованилин (2-гидрокси-3-метоксибензальдегид) (IIIa), $\beta$-резорциловый альдегид $(2,4$-дигидроксибензальдегид) (IVa), изованилин (3-гидрокси-4-

\footnotetext{
* Автор, с которым следует вести переписку.
} 
метоксибензальдегид) (Va), ванилин (4-гидрокси-3-метоксибензальдегид) (VIa), ванилаль (4-гидрокси-3этоксибензальдегид) (VIIa), протокатеховый альдегид (3,4-дигидроксибензальдегид) (VIIIa) [18, 19].

Целевые моно- (Іб, ІІб-д) и диалкоксибензальдегиды (IIIб, в, IVб-Г, Vб, в, VIб-н, VIIб-м, VIIIб, в) получали по реакции Вильямсона [20], специально модифицированной для достижения высокой степени конверсии исходных гидроксибензальдегидов (Ia-VIIIa) и чистоты образующихся соединений. Синтез проводили кипячением смеси исходных гидрокси- или дигидроксибензальдегидов (Ia-VIIIa), соответствующих бромалкилов, бромциклоалкилов или бензилхлорида, безводного карбоната калия в среде $96 \%$-ного этанола в течение 10-12 ч. Для предотвращения окисления альдегидной группы в карбоксильную в процессе проведения синтеза применяли барботирование через кипящую реакционную смесь слабого тока азота. Дополнительную очистку полученных моно- (Іб, ІІб-д) и диалкоксибензальдегидов (IIIб, в, IVб-г, Vб, в, VIб-н, VIIб-м, VIIIб, в) проводили низкотемпературной кристаллизацией из смеси бензола и гексана, или колоночной хроматографией на оксиде алюминия (II степени активности по Брокману, нейтральный), элюент - бензол [21].

Выход синтезированных по данному методу моно- и диалкоксибензальдегидов (Iб, ІІб-д, ІІІб, в, IVб-г, Vб, в, VIб-н, VIIб-м, VIIIб, в) составлял 66-89\%. Попытки использования вместо бромалкилов или бромциклоалкилов $\left(\mathrm{R}^{2} \mathrm{Br}\right)$ соответствующих хлоралкилов или хлорциклоалкилов $\left(\mathrm{R}^{2} \mathrm{Cl}\right)$, за исключением бензилхлорида, оказались безуспешными и не приводили к образованию моно- и диалкоксибензальдегидов.

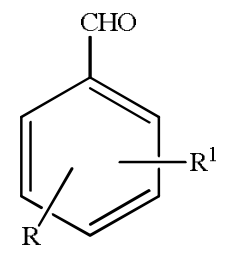

(Ia-VIIIa)

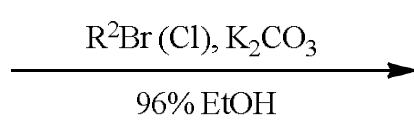

(Іб, ІІб-д, ІІІб, в, ІVб-г, Vб, в,

VІб-н, VІІб-м, VІІІб, в)

$\mathrm{R}=\mathrm{H}, 2-\mathrm{R}^{1}=\mathrm{OH}$ (Ia), $\mu$ - $\mathrm{BuO}$ (Iб); $\mathrm{R}=\mathrm{H}, 4-\mathrm{R}^{1}=\mathrm{OH}$ (IIa), $\mu$ - $\mathrm{BuO}$ (ІІб), $\mathrm{O}\left(\mathrm{CH}_{2}\right)_{14} \mathrm{Me}$ (ІІв), иикло- $\mathrm{C}_{6} \mathrm{H}_{11} \mathrm{O}$ (ІІг),

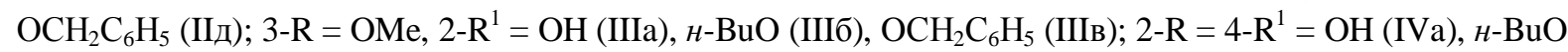
(IV6), $\mathrm{OCH}_{2} \mathrm{C}_{6} \mathrm{H}_{5}$ (IVB); 4-R = OMe, 3-R ${ }^{1}=\mathrm{OH}(\mathrm{Va}), \mu-\mathrm{BuO}(\mathrm{V} 6), \mathrm{OCH}_{2} \mathrm{C}_{6} \mathrm{H}_{5}$ (VB); 3-R = OMe, 4- $\mathrm{R}^{1}=\mathrm{OH}$ (VIa), EtO (VIб), OCHMe 2 (VIв), $\mu$ - $\mathrm{BuO}$ (VIг), $\mathrm{OCH}_{2} \mathrm{CHMe}_{2}$ (VIд), $\mathrm{O}\left(\mathrm{CH}_{2}\right)_{2} \mathrm{CHMe}_{2}$ (VIe), $\mathrm{O}\left(\mathrm{CH}_{2}\right)_{5} \mathrm{Me}$ (VIж), $\mathrm{O}\left(\mathrm{CH}_{2}\right)_{7} \mathrm{Me}$ (VI3), $\mathrm{O}\left(\mathrm{CH}_{2}\right)_{14} \mathrm{Me}$ (VIи), $\mathrm{OCH}_{2} \mathrm{C} \equiv \mathrm{CH}$ (VIк), иикло- $\mathrm{C}_{6} \mathrm{H}_{11} \mathrm{O}$ (VIл), иикло- $\mathrm{C}_{7} \mathrm{H}_{13} \mathrm{O}$ (VIм), $\mathrm{OCH}_{2} \mathrm{C}_{6} \mathrm{H}_{5}$

( $\mathrm{VIH}) ; 3-\mathrm{R}=\mathrm{OEt}, 4-\mathrm{R}^{1}=\mathrm{OH}$ (VIIa), EtO (VIIб), OCHMe 2 (VIIв), $\mu$ - $\mathrm{BuO}$ (VIIг), $\mathrm{OCH}_{2} \mathrm{CHMe}_{2}$ (VIIд), $\mathrm{O}\left(\mathrm{CH}_{2}\right)_{2} \mathrm{CHMe}_{2}$ (VIIe), $\mathrm{O}\left(\mathrm{CH}_{2}\right)_{5} \mathrm{Me}$ (VIIж), $\mathrm{O}\left(\mathrm{CH}_{2}\right)_{7} \mathrm{Me}(\mathrm{VII} 3), \mathrm{O}\left(\mathrm{CH}_{2}\right)_{14} \mathrm{Me}$ (VIIи), цикло- $\mathrm{C}_{6} \mathrm{H}_{11} \mathrm{O}$ (VIIк), цикло$\mathrm{C}_{7} \mathrm{H}_{13} \mathrm{O}$ (VIIл), OCH $\mathrm{C}_{6} \mathrm{H}_{5}$ (VIIм); 3-R = 4- $\mathrm{R}^{1}=\mathrm{OH}$ (VIIIa), $\mu$ - $\mathrm{BuO}$ (VIIIб), $\mathrm{OCH}_{2} \mathrm{C}_{6} \mathrm{H}_{5}$ (VIIIв)

Состав и строение синтезированных соединений (Іб, ІІб-д, ІІІб, в, ІVб-г, Vб, в, VІб-н, VІІб-м, VIIIб, в) доказаны данными спектров ИК и ЯМР ${ }^{1} \mathrm{H}$, данными элементного анализа и хромато-масс-спектрометрии. Полученные соединения (IVб-г, Vб, в, VIб-н, VIIб-м, VIIIб, в) обладают интенсивными ароматами фруктово-ягодной или цветочной направленности и являются перспективными субстратами для использования их в качестве ароматизаторов, душистых веществ и отдушек в пищевой и парфюмерной промышленности [22-25], а также могут служить доступными исходными соединениями для создания на их основе новых биологически активных веществ и разработки лекарственных препаратов медицинского или сельскохозяйственного назначения [16-18].

Органолептическая оценка ароматов некоторых из синтезированных моно- и диалкоксибензальдегидов проведена дегустационным советом при аккредитованной контрольно-аналитической лаборатории ООО «Тереза-Интер» (Москва, аттестат аккредитации Госстандарта РФ № POCC RU.0001.512.312 от 6.07.2000). Дегустацию проводили 12 экспертов-парфюмеров по десяти дескрипторам. Среднестатистические данные дегустации чистых продуктов приведены в таблице. Как и сложные эфиры ванилина и ванилаля [1], моно- и диалкоксибензальдегиды обладают перспективными ароматами для использования их в парфюмерной промышленности. 
Данные органолептической оценки ароматов некоторых моно- и диалкоксибензальдегидов

\begin{tabular}{|c|c|c|}
\hline № & Интенсивность запаха & Характер аромата \\
\hline Іб & очень сильный & древесно-озоновый, ноты аниса, водорослей, кожи, дыма \\
\hline ІІд & слабый & цветочный, ноты розы и лилии \\
\hline IV в & средний & ванильно-анисовый с нотой шоколада \\
\hline Vв & слабый & цветочный, яркая нота розы с ванильным оттенком \\
\hline VІб & средний & ванильно-древесный с приятными нотами кумина и тмина \\
\hline VIв & средний & ванильно-сливочный с древесной нотой \\
\hline VIг & Сильный & ванильно-древесный, пудровый, с выраженной модной металлической нотой \\
\hline VIд & средний & ванильно-древесный с землистым оттенком \\
\hline VIe & средний & ванильно-гвоздичный, нота шоколада, оттенок гваякола \\
\hline VІж & слабый & пряно-гвоздичный, грибной оттенок \\
\hline VI3 & слабый & ванильный, сладкий \\
\hline VІк & средний & древесно-куминовый со сладкой нотой ванили \\
\hline VIм & очень сильный & модные ароматы кожи, дерева с пряным дымным оттенком \\
\hline VIн & слабый & цветочно-ванильный с нотами лилии и белой сирени \\
\hline VІІб & слабый & ванильный, древесно-пудровый \\
\hline VIв & средний & цветочно-ванильный с гвоздичной нотой \\
\hline VII & слабый & ванильно-тминный \\
\hline VIIд & сильный & ванильно-сливочный с шоколадно-пудровой нотой \\
\hline VIIe & сильный & древесно-ванильный с выраженной нотой сладкой кожи \\
\hline VIIж & сильный & ванильный с выраженной нотой гелиотропа \\
\hline VII3 & сильный & озоново-цветочный, ноты настурции, цикламена, розы, аниса \\
\hline УПл & сильный & сладкий, древесно-кожаный, оттенок березового дегтя \\
\hline VIIM & средний & сладкий, древесно-анисовый, цветочные ноты сирени, лилии, гелиотропа \\
\hline VІІІб & слабый & ванильно-цветочный, ноты гелиотропа и сирени \\
\hline VIIIв & слабый & цветочно-древесный с мускусной нотой \\
\hline
\end{tabular}

\section{Экспериментальная часть}

ИК-спектры синтезированных соединений записаны на ИК Фурье-спектрофотометре Protege-460 фирмы «Nicolet» в тонком слое или в KBr. Спектры ЯМР ${ }^{1}$ Н получены на спектрометре BS-587A (100 MГц, Tesla) для 5\%-ных растворов в $\mathrm{CDCl}_{3}$, химические сдвиги определяли относительно внутреннего стандарта - тетраметилсилана. Масс-спектры получены на хромато-масс-спектрометре Hewlett-Packard HP 5890/5972 в режиме ионизации электронным ударом с энергией электронов 70 эВ; капиллярная колонка HP-5MS 30 м × 0,25 мм, фаза (5\% PhMe Silicone) 0,25 мкм, температура испарителя $-250{ }^{\circ} \mathrm{C}$.

Исходные альдегидофенолы были использованы (Ia-VIIIa) после предварительной очистки перегонкой или перекристаллизацией и имели физико-химические константы, соответствовавшие литературным данным [19].

Моно- (Іб, ІІб-д) и диалкоксибензальдегиды (IIб, в, IVб-г, Vб, в, VIб-н, VIIб-м, VIIб, в). Смесь 0,1 моль гидрокси- (Ia-IIIa, Va-VIIa) или 0,05 моль дигидроксибензальдегида (IVa, VIIIa), 0,11 моль соответствующего бромалкила, бромциклоалкила или бензилхлорида и 0,11 моль безводного карбоната калия кипятили с обратным холодильником в среде 96\%-ного этанола (200-250 мл) в течение 10-12 ч. Через кипящую реакционную смесь применяли барботирование слабого тока азота. После охлаждения реакционную смесь разбавляли 500 мл 10\%-ного водного раствора хлорида натрия. Выпавшие из реакционной смеси в виде осадков кристаллические целевые продукты (ІІв, д, ІІІв, IVб, г, Vб, в, VIг, ж-к, н, VIIг, ж-и, м) отделяли фильтрованием на стеклянном пористом фильтре, промывали водой (2-3 л), сушили при пониженном давлении (50-100 мм рт. ст. над осушителем $\mathrm{MgSO}_{4}$ или $\mathrm{Na}_{2} \mathrm{SO}_{4}$ ). Жидкие продукты (Iб, IIб, г, IIIб, IVв, VIв-е, л, м, VIIб, в, д, е, к, л) экстрагировали хлористым метиленом $(3 \times 150$ мл), растворитель удаляли, остатки вакуумировали. Дополнительную очистку полученных моно- (Іб, ІІб-д) и диалкоксибензальдегидов (IIIб, в, IVб-г, Vб, в, VIб-н, VIIб-м, VIIIб, в) проводили низкотемпературной кристаллизацией из смеси бензола и гексана, или колоночной хроматографией на оксиде алюминия (II степени активности по Брокману, нейтральный), элюент - бензол.

2-н-Бутоксибензальдегид (Іб). Выход $89 \%, d_{20}{ }^{20} 0,9846, n_{D}{ }^{20} 1,5360$, ИК-спектр, v, см${ }^{-1}: 3104,3070$, 3040, $3015\left(\mathrm{CH}_{\mathrm{Ar}}\right)$; 2959, 2935, $2873\left(\mathrm{CH}_{\mathrm{Alk}}\right) ; 2755\left(\mathrm{CH}_{\mathrm{CHO}}\right) ; 1674,1665,1646(\mathrm{C}=\mathrm{O}) ; 1620,1599,1582,1386(\mathrm{Ar})$; 1487, $1459\left(\mathrm{CH}_{2}\right) ; 1286,1243,1189,1161,1102,1006,972(\mathrm{C}-\mathrm{O}) ; 883,831,758,721\left(\mathrm{CH}_{\mathrm{Ar}}\right)$. Спектр ЯМР ${ }^{1} \mathrm{H}, \delta$, м.д.: 0,98 т (3H, Me), 1,25-2,05 м [4H, $\left.\left(\mathrm{CH}_{2}\right)_{2}\right], 4,06$ т $\left(2 \mathrm{H}, \mathrm{CH}_{2} \mathrm{O}\right), 6,75-7,95$ м $\left(4 \mathrm{H}, \mathrm{C}_{6} \mathrm{H}_{4}\right), 10,51 \mathrm{c}(1 \mathrm{H}, \mathrm{CHO})$. Масс-спектр: $m / z, 178[M]^{+}$. Найдено, \%: С 74,38; Н 8,10, $\mathrm{C}_{11} \mathrm{H}_{14} \mathrm{O}_{2}$. Вычислено, \%: С 74,13; Н 7,92, $M$ 178,23. 
4-н-Бутоксибензальдегид (ІІб). Выход 87\%, $d_{20}{ }^{20} 0,9961, n_{D}{ }^{20} 1,5405$, ИК-спектр, $v, \mathrm{~cm}^{-1}: 3070,3065$, $3013\left(\mathrm{CH}_{\mathrm{Ar}}\right)$; 2959, 2936, 2873, $2828\left(\mathrm{CH}_{\mathrm{Alk}}\right) ; 2736\left(\mathrm{CH}_{\mathrm{CHO}}\right) ; 1695(\mathrm{C}=\mathrm{O}) ; 1602,1577,1510,1394(\mathrm{Ar}) ; 1468$, $1428\left(\mathrm{CH}_{2}\right) ; 1313,1258,1216,1160,1110,1005,970(\mathrm{C}-\mathrm{O}) ; 833\left(\mathrm{CH}_{\mathrm{Ar}}\right)$. Спектр ЯМР ${ }^{1} \mathrm{H}, \delta$, м.д.: $0,96 \mathrm{~T}(3 \mathrm{H}$, $\mathrm{Me}), 1,25-2,04$ м [4H, $\left.\left(\mathrm{CH}_{2}\right)_{2}\right], 4,01$ т $\left(2 \mathrm{H}, \mathrm{CH}_{2} \mathrm{O}\right), 6,75-7,95$ м $\left(4 \mathrm{H}, \mathrm{C}_{6} \mathrm{H}_{4}\right), 9,85$ с $(1 \mathrm{H}, \mathrm{CHO})$. Масс-спектр: $m / z$ $178[M]^{+}$. Найдено, \%: С 74,33; Н 8,13, $\mathrm{C}_{11} \mathrm{H}_{14} \mathrm{O}_{2}$. Вычислено, \%: С 74,13; Н 7,92, $M$ 178,23.

4-н-Пентадеканоксибензальдегид (ІІв). Выход 89\%, т. пл. 45-46 ${ }^{\circ} \mathrm{C}$. ИК-спектр, v, см${ }^{-1}: 3070,3035$, $3015\left(\mathrm{CH}_{\mathrm{Ar}}\right) ; 2954,2916,2849,2810\left(\mathrm{CH}_{\mathrm{Alk}}\right) ; 2739\left(\mathrm{CH}_{\mathrm{CHO}}\right) ; 1688(\mathrm{C}=\mathrm{O}) ; 1606,1580,1510,1403(\mathrm{Ar}) ; 1470,1430$ $\left(\mathrm{CH}_{2}\right) ; 1318,1268,1218,1164,1109,1011,972(\mathrm{C}-\mathrm{O}) ; 859,831,718\left(\mathrm{CH}_{\mathrm{Ar}}\right)$. Спектр ЯМР ${ }^{1} \mathrm{H}, \delta$, м.д.: 0,89 т (3Н, $\mathrm{Me}), 1,26$ уш. с [24H, $\left.\left(\mathrm{CH}_{2}\right)_{12}\right], 1,95$ т $\left(2 \mathrm{H}, \mathrm{CH}_{2}\right), 4,14$ т $\left(2 \mathrm{H}, \mathrm{CH}_{2} \mathrm{O}\right), 6,72-7,98$ м $\left(4 \mathrm{H}, \mathrm{C}_{6} \mathrm{H}_{4}\right), 9,84$ c $(1 \mathrm{H}, \mathrm{CHO})$. Масс-спектр: $m / z 332$ [M] $]^{+}$. Найдено, \%: С 79,94; Н 10,15, $\mathrm{C}_{22} \mathrm{H}_{36} \mathrm{O}_{2}$, Вычислено, \%: С 79,46; Н 10,91, M 332,52.

4-Циклогексилоксибензальдегид (ІІг). Выход 66\%, $d_{20}{ }^{20} 1,1012, n_{D}{ }^{20} 1,5610$, ИК-спектр, $v, \mathrm{~cm}^{-1}$ : 3073, $3026\left(\mathrm{CH}_{\mathrm{Ar}}\right) ; 2936,2858\left(\mathrm{CH}_{\mathrm{Alk}}\right) ; 2735\left(\mathrm{CH}_{\mathrm{CHO}}\right) ; 1689(\mathrm{C}=\mathrm{O}) ; 1600,1574,1507(\mathrm{Ar}) ; 1449,1429\left(\mathrm{CH}_{2}\right)$; 1309, 1258, 1217, 1160, 1110, 1043, 1020, $967(\mathrm{C}-\mathrm{O}) ; 860,834\left(\mathrm{CH}_{\mathrm{Ar}}\right)$. Спектр ЯМР ${ }^{1} \mathrm{H}, \delta$, м.д.: 1,10-2,30 м [10H, $\left.\left(\mathrm{CH}_{2}\right)_{5}\right], 4,37$ уш. с $(1 \mathrm{H}, \mathrm{CH}), 6,72-7,95$ м $\left(4 \mathrm{H}, \mathrm{C}_{6} \mathrm{H}_{4}\right), 9,86$ с (1H, СНО). Масс-спектр: $\mathrm{m} / z 204[M]^{+}$. Найдено, \%: С 76,80; Н 8,07, $\mathrm{C}_{13} \mathrm{H}_{16} \mathrm{O}_{2}$. Вычислено, \%: С 76,44; Н 7,90, $M$ 204,26.

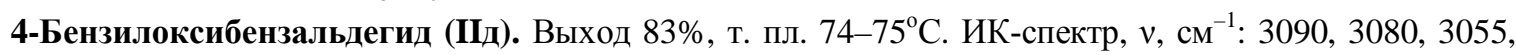
3036, $3008\left(\mathrm{CH}_{\mathrm{Ar}}\right)$; 2940, 2829, $2803\left(\mathrm{CH}_{\mathrm{Alk}}\right) ; 2745\left(\mathrm{CH}_{\mathrm{CHO}}\right) ; 1687(\mathrm{C}=\mathrm{O}) ; 1601,1575,1509,1425,1394(\mathrm{Ar})$; 1462, $1452\left(\mathrm{CH}_{2}\right) ; 1330,1301,1261,1214,1165,1110,1018(\mathrm{C}-\mathrm{O}) ; 867,832,735,696\left(\mathrm{CH}_{\mathrm{Ar}}\right)$. Спектр ЯМР ${ }^{1} \mathrm{H}$, $\delta$, м.д.: 5,15 с $\left(2 \mathrm{H}, \mathrm{CH}_{2} \mathrm{O}\right), 7,07-7,85$ м $\left(9 \mathrm{H}, \mathrm{C}_{6} \mathrm{H}_{4}\right.$ и $\left.\mathrm{C}_{6} \mathrm{H}_{5}\right), 9,89$ с $(1 \mathrm{H}, \mathrm{CHO})$. Масс-спектр: $\mathrm{m} / z 212[M]^{+}$. Найдено, \%: С 79,48; Н 5,93, $\mathrm{C}_{14} \mathrm{H}_{12} \mathrm{O}_{2}$. Вычислено, \%: С 79,22; Н 5,70, $M$ 212,24.

2-н-Бутокси-3-метоксибензальдегид (ІІІб). Выход 80\%, $d_{20}{ }^{20} 0,9451, n_{D}{ }^{20} 1,5235$, ИК-спектр, $v, \mathrm{~cm}^{-1}$ : 3090, 3070, $3005\left(\mathrm{CH}_{\mathrm{Ar}}\right) ; 2959,2936,2871,2841\left(\mathrm{CH}_{\mathrm{Alk}}\right) ; 2736\left(\mathrm{CH}_{\mathrm{CHO}}\right) ; 1692(\mathrm{C}=\mathrm{O}) ; 1594,1584,1483,1378$ (Ar); 1456, $1442\left(\mathrm{CH}_{2}\right) ; 1312,1265,1249,1185,1067,1022(\mathrm{C}-\mathrm{O}) ; 785,764\left(\mathrm{CH}_{\mathrm{Ar}}\right)$. Спектр ЯМР ${ }^{1} \mathrm{H}, \delta$, м.д.: 0,96 т (3H, Me), 1,25-1,98 м [4H, $\left.\left(\mathrm{CH}_{2}\right)_{2}\right], 3,87$ с $(3 \mathrm{H}, \mathrm{MeO}), 4,12$ т $\left(2 \mathrm{H}, \mathrm{CH}_{2} \mathrm{O}\right), 6,90-6,55$ м $\left(3 \mathrm{H}, \mathrm{C}_{6} \mathrm{H}_{3}\right), 10,45$ с (1Н, СНО). Масс-спектр: $m / z 208[M]^{+}$. Найдено, \%: С 69,45; Н 7,81, $\mathrm{C}_{12} \mathrm{H}_{16} \mathrm{O}_{3}$. Вычислено, \%: С 69,21; H 7,74, M 208,25.

2-Бензилокси-3-метоксибензальдегид (ІІв). Выход 74\%, т. пл. 33-34 ${ }^{\circ} \mathrm{C}$. ИК-спектр, $v$, см$^{-1}: 3090$, 3061, 3030, $3007\left(\mathrm{CH}_{\mathrm{Ar}}\right)$; 2967, 2940, 2899, 2878, $2840\left(\mathrm{CH}_{\mathrm{Alk}}\right) ; 2776,2746\left(\mathrm{CH}_{\mathrm{CHO}}\right) ; 1694(\mathrm{C}=\mathrm{O}) ; 1594,1584$, 1480, 1390, 1367 (Ar); 1455, $1439\left(\mathrm{CH}_{2}\right)$; 1307, 1267, 1247, 1190, 1081, 1062, 968 (C-O); 919, 908, 858, 780, 765, 753, $698\left(\mathrm{CH}_{\mathrm{Ar}}\right)$. Спектр ЯМР ${ }^{1} \mathrm{H}, \delta$, м.д.: 3,94 с $(3 \mathrm{H}, \mathrm{MeO}), 5,20$ с $\left(2 \mathrm{H}, \mathrm{CH}_{2}\right), 7,10-7,45 \mathrm{м}\left(8 \mathrm{H}, \mathrm{C}_{6} \mathrm{H}_{3}\right.$ и $\left.\mathrm{C}_{6} \mathrm{H}_{5}\right), 10,27$ с (1Н, СНО). Масс-спектр: $m / z 242[M]^{+}$. Найдено, \%: С 74,66; Н 5,99, $\mathrm{C}_{15} \mathrm{H}_{14} \mathrm{O}_{3}$. Вычислено, $\%$ : C 74,36; H 5,82, $M$ 242,27.

2,4-Диэтоксибензальдегид (IVб). Выход 85\%, т. пл. 70-71 ${ }^{\circ} \mathrm{C}$. ИК-спектр, $v, \mathrm{~cm}^{-1}:$ 3090, 3075, 3040 $\left(\mathrm{CH}_{\mathrm{Ar}}\right) ; 2981,2950,2931,2902,2859\left(\mathrm{CH}_{\mathrm{Alk}}\right) ; 2773\left(\mathrm{CH}_{\mathrm{CHO}}\right) ; 1672(\mathrm{C}=\mathrm{O}) ; 1606,1590,1570,1498,1402(\mathrm{Ar})$; 1470, 1760, 1452, $1442\left(\mathrm{CH}_{2}\right) ; 1328,1262,1230,1187,1117,1095,1045,999(\mathrm{C}-\mathrm{O}) ; 915,854,819,808,676$ $\left(\mathrm{CH}_{\mathrm{Ar}}\right)$. Спектр ЯМР ${ }^{1} \mathrm{H}, \delta$, м.д.: 1,30-1,57 м $(6 \mathrm{H}, 2 \mathrm{Me}), 4,88-4,30$ м $\left(4 \mathrm{H}, 2 \mathrm{CH}_{2}\right), 6,25-7,85$ м $\left(3 \mathrm{H}, \mathrm{C}_{6} \mathrm{H}_{3}\right), 10,30$ c (1Н, СНО). Масс-спектр: m/z $194[M]^{+}$. Найдено, \%: С 68,43; Н 7,34, $\mathrm{C}_{11} \mathrm{H}_{14} \mathrm{O}_{3}$. Вычислено, \%: С 68,02; H 7,27, $M$ 194,23.

2,4-Ди-н-бутоксибензальдегид (IVв). Выход $81 \%, d_{20}{ }^{20} 1,0488, n_{D}{ }^{20} 1,5280$, ИК-спектр, $v, \mathrm{~cm}^{-1}: 3093$, 3070, $3035\left(\mathrm{CH}_{\mathrm{Ar}}\right) ; 2959,2935,2873\left(\mathrm{CH}_{\mathrm{Alk}}\right) ; 2761\left(\mathrm{CH}_{\mathrm{CHO}}\right) ; 1679,1630(\mathrm{C}=\mathrm{O}) ; 1601,1576,1505,1390(\mathrm{Ar})$; 1467, $1436\left(\mathrm{CH}_{2}\right)$; 1334, 1293, 1261, 1224, 1187, 1115, 1067, 1010, 987 (C-O); 817, 805, $760\left(\mathrm{CH}_{\mathrm{Ar}}\right)$. Спектр ЯМР ${ }^{1} \mathrm{H}, \delta$, м.д.: 0,97 т $(6 \mathrm{H}, 2 \mathrm{Me}), 1,15-2,10$ м [8H, 2( $\left.\left.\mathrm{CH}_{2}\right)_{2}\right], 3,80-4,30$ м $\left(4 \mathrm{H}, 2 \mathrm{CH}_{2} \mathrm{O}\right), 6,27-7,88$ м (3H, $\left.\mathrm{C}_{6} \mathrm{H}_{3}\right), 10,31$ с (1Н, СНО). Масс-спектр: $m / z 250[M]^{+}$. Найдено, \%: С 72,29; Н 9,03, $\mathrm{C}_{15} \mathrm{H}_{22} \mathrm{O}_{3}$. Вычислено, \%: C 71,97; H 8,86, $M$ 250,33.

2,4-Дибензилоксибензальдегид (IVг). Выход 75\%, т. пл. 85-86 ${ }^{\circ}$. ИК-спектр, v, см ${ }^{-1}: 3090,3065$, $3034\left(\mathrm{CH}_{\mathrm{Ar}}\right)$; 2964, 2925, 2870, $2847\left(\mathrm{CH}_{\mathrm{Alk}}\right) ; 2764\left(\mathrm{CH}_{\mathrm{CHO}}\right) ; 1670(\mathrm{C}=\mathrm{O}) ; 1607,1578,1501,1436,1369(\mathrm{Ar})$; $1460\left(\mathrm{CH}_{2}\right) ; 1331,1260,1218,1185,1100,1016(\mathrm{C}-\mathrm{O}) ; 833,818,740,731,698,674\left(\mathrm{CH}_{\mathrm{Ar}}\right)$. Спектр ЯMР ${ }^{1} \mathrm{H}, \delta$, м.д.: 5,12 с и 5,15 с $\left(4 \mathrm{H}, 2 \mathrm{CH}_{2} \mathrm{O}\right), 6,50-7,95$ м $\left(13 \mathrm{H}, 2 \mathrm{C}_{6} \mathrm{H}_{5}\right.$ и $\left.\mathrm{C}_{6} \mathrm{H}_{3}\right), 10,42$ с (1Н, СНО). Масс-спектр: $m / z, 318$ $[M]^{+}$. Найдено, \%: С 79,61; Н 5,92, $\mathrm{C}_{21} \mathrm{H}_{18} \mathrm{O}_{3}$. Вычислено, \%: С 79,22; Н 5,70, M 318,37.

3-н-Бутокси-4-метоксибензальдегид (Уб). Выход 83\%, т. пл. 38-39 С. ИК-спектр, $v$, см$^{-1}: 3080$, $3011\left(\mathrm{CH}_{\mathrm{Ar}}\right) ; 2959,2935,2872,2841\left(\mathrm{CH}_{\mathrm{Alk}}\right) ; 2766\left(\mathrm{CH}_{\mathrm{CHO}}\right) ; 1687(\mathrm{C}=\mathrm{O}) ; 1587,1512,1394(\mathrm{Ar}) ; 1463,1437$ $\left(\mathrm{CH}_{2}\right) ; 1341,1267,1240,1163,1135,1022(\mathrm{C}-\mathrm{O}) ; 867,810,740\left(\mathrm{CH}_{\mathrm{Ar}}\right)$. Спектр ЯМР ${ }^{1} \mathrm{H}, \delta$, м.д.: 0,92 т (3Н, 
$\mathrm{Me}), 1,22-2,00$ м [ $\left.4 \mathrm{H},\left(\mathrm{CH}_{2}\right)_{2}\right], 3,81$ с $(3 \mathrm{H}, \mathrm{MeO}), 4,00$ т $\left(2 \mathrm{H}, \mathrm{CH}_{2} \mathrm{O}\right), 6,72-7,45$ м (3H, $\left.\mathrm{C}_{6} \mathrm{H}_{3}\right), 9,77$ с (1H, CHO). Масс-спектр: $m / z 208[M]^{+}$. Найдено, \%: С 69,53; Н 7,96, $\mathrm{C}_{12} \mathrm{H}_{16} \mathrm{O}_{3}$. Вычислено, \%: С 69,21; Н 7,74, $M$ 208,25.

3-Бензилокси-4-метоксибензальдегид (Vв). Выход 82\%, т. пл. 64-65 ${ }^{\circ} \mathrm{C}$. ИК-спектр, $v, \mathrm{~cm}^{-1}: 3072$, 3046, 3035, $3009\left(\mathrm{CH}_{\mathrm{Ar}}\right)$; 2964, 2932, 2872, 2840, $2812\left(\mathrm{CH}_{\mathrm{Alk}}\right) ; 2749,2718\left(\mathrm{CH}_{\mathrm{CHO}}\right) ; 1677(\mathrm{C}=\mathrm{O}) ; 1596,1583$, 1506, 1390, 1383 (Ar); 1457, $1432\left(\mathrm{CH}_{2}\right)$; 1260, 1236, 1159, 1009 (C-O); 872, 851, 807, 766, 736, 697, $640\left(\mathrm{CH}_{\mathrm{Ar}}\right)$. Спектр ЯМР ${ }^{1} \mathrm{H}, \delta$, м.д.: 3,96 с (3H, MeO), 5,19 с $\left(2 \mathrm{H}, \mathrm{CH}_{2}\right), 6,99-7,48$ м $\left(8 \mathrm{H}_{1} \mathrm{C}_{6} \mathrm{H}_{3}\right.$ и $\left.\mathrm{C}_{6} \mathrm{H}_{5}\right), 9,82$ с $(1 \mathrm{H}, \mathrm{CHO})$. Масс-спектр: $m / z 242[M]^{+}$. Найдено, \%: С 74,79; Н 5,92, $\mathrm{C}_{15} \mathrm{H}_{14} \mathrm{O}_{3}$. Вычислено, \%: С 74,36; Н 5,82, $M$ 242,27.

3-Метокси-4-этоксибензальдегид (VIб). Выход 88\%, т. пл. 57-58 ${ }^{\circ} \mathrm{C}$. ИК-спектр, v, см$^{-1}: 3083,3057$, 3040, $3000\left(\mathrm{CH}_{\mathrm{Ar}}\right) ; 2980,2942,2094,2890,2855\left(\mathrm{CH}_{\mathrm{Alk}}\right) ; 2767\left(\mathrm{CH}_{\mathrm{CHO}}\right) ; 1699,1683,1675(\mathrm{C}=\mathrm{O}) ; 1598,1584$, 1509, 1393 (Ar); 1477, $1463\left(\mathrm{CH}_{2}\right)$; 1266, 1238, 1137, 1044, 1028 (C-O); 921, 860, 804, 733, $656\left(\mathrm{CH}_{\mathrm{Ar}}\right)$. Спектр ЯMP ${ }^{1} \mathrm{H}, \delta$, м.д.: 1,46 т (3H, Me), 3,89 с (3H, MeO), 4,15 к (2H, $\left.\mathrm{CH}_{2} \mathrm{O}\right), 6,85-7,50$ м $\left(3 \mathrm{H}, \mathrm{C}_{6} \mathrm{H}_{3}\right), 9,80$ с $(1 \mathrm{H}, \mathrm{CHO})$. Масс-спектр: $m / z 180[M]^{+}$. Найдено, \%: С 67,04; Н 6,66, $\mathrm{C}_{10} \mathrm{H}_{12} \mathrm{O}_{3}$. Вычислено, \%: С 66,65; Н 6,71, $M$ 180,20.

3-Метокси-4-изо-пропоксибензальдегид (VІв). Выход $68 \%, d_{20}{ }^{20} 1,0004, n_{D}{ }^{20} 1,5490$, ИК-спектр, $v$, $\mathrm{cm}^{-1}$ : 3080, $3024\left(\mathrm{CH}_{\mathrm{Ar}}\right) ; 2979,2936,2833\left(\mathrm{CH}_{\mathrm{Alk}}\right) ; 2740,2729\left(\mathrm{CH}_{\mathrm{CHо}}\right) ; 1685(\mathrm{C}=\mathrm{O}) ; 1594,1584,1507,1386$ (Ar); 1268, 1237, 1135, 1109, 1033, 950 (C-O); 866, 813, 781, 731, $655\left(\mathrm{CH}_{\mathrm{Ar}}\right)$. Спектр ЯМР ${ }^{1} \mathrm{H}, \delta$, м.д.: 1,34 д $\left(6 \mathrm{H}, \mathrm{Me}_{2} \mathrm{C}\right), 3,84$ с $(3 \mathrm{H}, \mathrm{MeO}), 4,61$ септ $(1 \mathrm{H}, \mathrm{CH}), 6,76-7,42$ м $\left(3 \mathrm{H}, \mathrm{C}_{6} \mathrm{H}_{3}\right), 9,77$ с (1H, CHO). Масс-спектр: $m / z, 194[M]^{+}$. Найдено, \%: С 68,31; Н 7,46, С $\mathrm{C}_{11} \mathrm{H}_{14} \mathrm{O}_{3}$. Вычислено, \%: С 68,02; Н 7,27, $M$ 194,23.

4-н-Бутокси-3-метоксибензальдегид (VIг). Выход 85\%, т. пл. 31-32 ${ }^{\circ} \mathrm{C}$. ИК-спектр, v, см ${ }^{-1}: 3072$, 3060, $3003\left(\mathrm{CH}_{\mathrm{Ar}}\right) ; 2959,2937,2873,2835\left(\mathrm{CH}_{\mathrm{Alk}}\right) ; 2761,2732\left(\mathrm{CH}_{\mathrm{CHO}}\right) ; 1682(\mathrm{C}=\mathrm{O}) ; 1596,1585,1510,1397$ (Ar); 1466, $1424\left(\mathrm{CH}_{2}\right) ; 1332,1267,1239,1159,1136,1023(\mathrm{C}-\mathrm{O}) ; 868,819,772,731\left(\mathrm{CH}_{\mathrm{Ar}}\right)$. Спектр ЯMP ${ }^{1} \mathrm{H}$, $\delta$, м.д.: 0,96 т (3H, Me), 1,25-2,10 м [4H, $\left.\left(\mathrm{CH}_{2}\right)_{2}\right], 3,89$ с $(3 \mathrm{H}, \mathrm{MeO}), 4,11$ т $\left(2 \mathrm{H}, \mathrm{CH}_{2} \mathrm{O}\right), 6,85-7,55$ м $(3 \mathrm{H}$, $\left.\mathrm{C}_{6} \mathrm{H}_{3}\right), 9,81$ с (1H, СНО). Масс-спектр: $m / z 208[M]^{+}$. Найдено, \%: С 69,60; Н 7,87, $\mathrm{C}_{12} \mathrm{H}_{16} \mathrm{O}_{3}$. Вычислено, \%: C 69,21; H 7,74, $M$ 208,25.

4-изо-Бутокси-3-метоксибензальдегид (VIд). Выход $68 \%, d_{20}{ }^{20} 0,9842, n_{D}{ }^{20} 1,5460$, ИК-спектр, $v$, см': 3080, 3060, $3004\left(\mathrm{CH}_{\mathrm{Ar}}\right) ; 2960,2937,2918,2874,2834\left(\mathrm{CH}_{\mathrm{Alk}}\right) ; 2762,2730\left(\mathrm{CH}_{\mathrm{CHO}}\right) ; 1683(\mathrm{C}=\mathrm{O}) ; 1596,1586$, 1510, 1397 (Ar); 1467, $1424\left(\mathrm{CH}_{2}\right) ; 1341,1268,1239,1159,1136,1021(\mathrm{C}-\mathrm{O}) ; 867,809,782,731,653\left(\mathrm{CH}_{\mathrm{Ar}}\right)$. Спектр ЯМР ${ }^{1} \mathrm{H}, \delta$, м.д.: 1,03 д (6H, $\left.\mathrm{Me}_{2} \mathrm{C}\right), 1,70-2,45$ м $(1 \mathrm{H}, \mathrm{CH}), 3,84$ д $\left(2 \mathrm{H}, \mathrm{CH}_{2}\right), 3,89$ с $(3 \mathrm{H}, \mathrm{MeO}), 6,82-$ 7,53 м (3H, $\left.\mathrm{C}_{6} \mathrm{H}_{3}\right), 9,82$ с (1H, СНО). Масс-спектр: $m / z 208[M]^{+}$. Найдено, \%: С 69,33; Н 7,64, $\mathrm{C}_{12} \mathrm{H}_{16} \mathrm{O}_{3}$. Вычислено, \%: С 69,21; Н 7,74, $M$ 208,25.

4-изо-Амилокси-3-метоксибензальдегид (VIе). Выход 70\%, $d_{20}{ }^{20} 1,0967, n_{D}{ }^{20} 1,5445$, ИК-спектр, $v$, $\mathrm{cm}^{-1}$ : 3070, 3056, $3003\left(\mathrm{CH}_{\mathrm{Ar}}\right) ; 2956,2936,2871,2835\left(\mathrm{CH}_{\mathrm{Alk}}\right) ; 2763,2729\left(\mathrm{CH}_{\mathrm{CHO}}\right) ; 1683(\mathrm{C}=\mathrm{O}) ; 1596,1586$, 1510, 1397 (Ar); 1466, $1425\left(\mathrm{CH}_{2}\right)$; 1340, 1267, 1240, 1159, 1136, 1034, 1009, 977 (C-O); 871, 812, 766, 731 $\left(\mathrm{CH}_{\mathrm{Ar}}\right)$. Спектр ЯМР ${ }^{1} \mathrm{H}, \delta$, м.д.: 0,92 д (6H, $\left.\mathrm{Me}_{2} \mathrm{C}\right), 1,55-1,95$ м $\left(3 \mathrm{H}, \mathrm{CH}_{2}\right.$ и $\left.\mathrm{CH}\right), 3,84$ с $(3 \mathrm{H}, \mathrm{MeO}), 4,06$ т $(2 \mathrm{H}$, $\left.\mathrm{CH}_{2} \mathrm{O}\right), 6,85-7,41$ м (3Н, $\left.\mathrm{C}_{6} \mathrm{H}_{3}\right), 9,77$ с (1H, СНО). Масс-спектр: $m / z 222[M]^{+}$. Найдено, \%: С 70,65; Н 8,29, $\mathrm{C}_{13} \mathrm{H}_{18} \mathrm{O}_{3}$. Вычислено, \%: С 70,24; Н 8,16, $M$ 222,28.

4-н-Гексилокси-3-метоксибензальдегид (VIж). Выход 89\%, т. пл. 34-35 $5^{\circ}$. ИК-спектр, v, см${ }^{-1}$ : 3070, 3058, $3004\left(\mathrm{CH}_{\mathrm{Ar}}\right)$; 2957, 2931, 2871, $2858\left(\mathrm{CH}_{\mathrm{Alk}}\right)$; 2762, $2722\left(\mathrm{CH}_{\mathrm{CHO}}\right) ; 1685(\mathrm{C}=\mathrm{O}) ; 1596,1586,1510$, 1396 (Ar); 1466, $1424\left(\mathrm{CH}_{2}\right)$; 1340, 1268, 1240, 1159, 1136, 1035, $1020(\mathrm{C}-\mathrm{O})$; 868, 807, 782, $731\left(\mathrm{CH}_{\mathrm{Ar}}\right)$. Спектр ЯMР ${ }^{1} \mathrm{H}, \delta$, м.д.: 0,90 т (3H, Me), 1,15-1,60 м [6H, $\left.\left(\mathrm{CH}_{2}\right)_{3}\right], 1,85$ т $\left(2 \mathrm{H}, \mathrm{CH}_{2}\right), 3,91$ с $(3 \mathrm{H}, \mathrm{MeO}), 4,09$ т $\left(2 \mathrm{H}, \mathrm{CH}_{2} \mathrm{O}\right), 6,78-7,51$ м $\left(3 \mathrm{H}, \mathrm{C}_{6} \mathrm{H}_{3}\right), 9,83$ с $(1 \mathrm{H}, \mathrm{CHO})$. Масс-спектр: $m / z 236[M]^{+}$. Найдено, \%: С 71,38; $\mathrm{H} \mathrm{8,72,} \mathrm{C}_{14} \mathrm{H}_{20} \mathrm{O}_{3}$. Вычислено, \%: С 71,16; Н 8,53, $M$ 236,31.

3-Метокси-4-н-октилоксибензальдегид (VI3). Выход 86\%, т. пл. 30-31 ${ }^{\circ} \mathrm{C}$. ИК-спектр, $v, \mathrm{~cm}^{-1}: 3081$, $3005\left(\mathrm{CH}_{\mathrm{Ar}}\right) ; 2978,2956,2934,2919,2875,2854\left(\mathrm{CH}_{\mathrm{Alk}}\right) ; 2762,2723\left(\mathrm{CH}_{\mathrm{CHO}}\right) ; 1689,1684,1670(\mathrm{C}=\mathrm{O}) ; 1596$, 1585, 1510, 1392 (Ar); 1467, $1426\left(\mathrm{CH}_{2}\right)$; 1276, 1270, 1238, 1159, 1136, $1028(\mathrm{C}-\mathrm{O}) ; 868,805,732,658\left(\mathrm{CH}_{\mathrm{Ar}}\right)$. Спектр ЯМР ${ }^{1} \mathrm{H}, \delta$, м.д.: 0,89 т (3H, Me), 1,12-1,70 м [10H, $\left.\left(\mathrm{CH}_{2}\right)_{5}\right], 1,91$ т $\left(2 \mathrm{H}, \mathrm{CH}_{2}\right), 3,93 \mathrm{c}(3 \mathrm{H}, \mathrm{MeO}), 4,10$ т $\left(2 \mathrm{H}, \mathrm{CH}_{2} \mathrm{O}\right), 6,78-7,52$ м $\left(3 \mathrm{H}, \mathrm{C}_{6} \mathrm{H}_{3}\right), 9,85$ с $(1 \mathrm{H}, \mathrm{CHO})$. Масс-спектр: $m / z 264[M]^{+}$. Найдено, \%: С 73,03; Н 9,19, $\mathrm{C}_{16} \mathrm{H}_{24} \mathrm{O}_{3}$. Вычислено, \%: С 72,69; Н 9,15, $M$ 264,36.

3-Метокси-4-н-пентадеканоксибензальдегид (VIи). Выход 82\%, т. пл. 44-45 ${ }^{\circ}$. ИК-спектр, $v, \mathrm{~cm}^{-1}$ : 3078, $2998\left(\mathrm{CH}_{\mathrm{Ar}}\right) ; 2960,2917,2850\left(\mathrm{CH}_{\mathrm{Alk}}\right) ; 2756,2740\left(\mathrm{CH}_{\mathrm{CHO}}\right) ; 1698,1679(\mathrm{C}=\mathrm{O}) ; 1596,1585,1512,1392$ (Ar); 1467, 1457, $1426\left(\mathrm{CH}_{2}\right) ; 1272,1236,1159,1141,1071,1027,1009$ (C-O); 880, 860, 802, 732, 720, 658 $\left(\mathrm{CH}_{\mathrm{Ar}}\right)$. Спектр ЯMР ${ }^{1} \mathrm{H}, \delta$, м.д.: 0,89 т (3Н, Me), 1,26 уш. с [24H, $\left.\left(\mathrm{CH}_{2}\right)_{12}\right], 1,89$ т $\left(2 \mathrm{H}, \mathrm{CH}_{2}\right), 3,93$ с $(3 \mathrm{H}, \mathrm{MeO})$, 
4,10 т $\left(2 \mathrm{H}, \mathrm{CH}_{2} \mathrm{O}\right), 6,87-7,52$ м $\left(3 \mathrm{H}, \mathrm{C}_{6} \mathrm{H}_{3}\right), 9,85$ с (1H, СНО). Масс-спектр: $m / z, 362[M]^{+}$. Найдено, \%: С 76,64; Н 10,88, $\mathrm{C}_{23} \mathrm{H}_{38} \mathrm{O}_{3}$. Вычислено, \%: С 76,20; Н 10,56, M 362,55.

3-Метокси-4-пропаргилоксибензальдегид (VIк). Выход 79\%, т. пл. 83-84 ${ }^{\circ} \mathrm{C}$. ИК-спектр, $v, \mathrm{~cm}^{-1}$ : 3249 ( $=\mathrm{C}-\mathrm{H}) ; 3077,3009\left(\mathrm{CH}_{\mathrm{Ar}}\right) ; 2977,2960,2923,2865,2852,2830\left(\mathrm{CH}_{\mathrm{Alk}}\right) ; 2765,2740\left(\mathrm{CH}_{\mathrm{CHO}}\right) ; 2127(\mathrm{C} \equiv \mathrm{C})$; 1702, 1688, $1669(\mathrm{C}=\mathrm{O}) ; 1599,1588,1508,1409,1380(\mathrm{Ar}) ; 1471,1451,1432\left(\mathrm{CH}_{2}\right) ; 1281,1267,1244,1158$, 1135, 1035, $1003(\mathrm{C}-\mathrm{O}) ; 862,805,735,692,658\left(\mathrm{CH}_{\mathrm{Ar}}\right)$. Спектр ЯМР ${ }^{1} \mathrm{H}, \delta$, м.д.: 2,57 т $(1 \mathrm{H},(\equiv \mathrm{CH}), 3,93 \mathrm{c}(3 \mathrm{H}$, $\mathrm{MeO}), 4,85$ д (2H, $\left.\mathrm{CH}_{2}\right), 7,05-7,58$ м $\left(3 \mathrm{H}, \mathrm{C}_{6} \mathrm{H}_{3}\right), 9,86$ с (1H, СНО). Масс-спектр: $m / z 190[M]^{+}$. Найдено, \%: С 69,87; Н 5,47, $\mathrm{C}_{11} \mathrm{H}_{10} \mathrm{O}_{3}$. Вычислено, \%: С 69,46; Н 5,30, $M$ 190,20.

3-Метокси-4-циклогексилоксибензальдегид (VIл). Выход 66\%, $d_{20}{ }^{20} 1,1457, n_{D}^{20} 1,5625$, ИКспектр, v, см ${ }^{-1}$ : 3077, $3004\left(\mathrm{CH}_{\mathrm{Ar}}\right) ; 2936,2857\left(\mathrm{CH}_{\mathrm{Alk}}\right) ; 2757,2730\left(\mathrm{CH}_{\mathrm{CHо}}\right) ; 1683(\mathrm{C}=\mathrm{O}) ; 1595,1583,1506$, 1424, 1396 (Ar); 1465, $1452\left(\mathrm{CH}_{2}\right)$; 1336, 1267, 1237, 1159, 1136, 1033, 967 (C-O); 866, 812, 782, 730, 652 $\left(\mathrm{CH}_{\mathrm{Ar}}\right)$. Спектр ЯМР ${ }^{1} \mathrm{H}, \delta$, м.д.: 0,95-2,25 м [10H, $\left.\left(\mathrm{CH}_{2}\right)_{5}\right], 3,83$ с (3H, MeO), 4,32 уш. с (1H, CH), 6,80-7,42 м $\left(3 \mathrm{H}, \mathrm{C}_{6} \mathrm{H}_{3}\right), 9,76$ c (1Н, СНО). Масс-спектр: $m / z 234[M]^{+}$. Найдено, \%: С 72,18; Н 8,01, $\mathrm{C}_{14} \mathrm{H}_{18} \mathrm{O}_{3}$. Вычислено, $\%$ : C 71,77; H 7,74, $M$ 234,29.

3-Метокси-4-циклогептилоксибензальдегид (VIм). Выход 69\%, $d_{20}{ }^{20} 1,0888, n_{D}^{20} 1,5675$, ИКспектр, v, см ${ }^{-1}$ : 3076, $3002\left(\mathrm{CH}_{\mathrm{Ar}}\right) ; 2931,2857\left(\mathrm{CH}_{\mathrm{Alk}}\right) ; 2756,2724\left(\mathrm{CH}_{\mathrm{CHO}}\right) ; 1682(\mathrm{C}=\mathrm{O}) ; 1595,1583,1505$, 1424, 1395 (Ar); $1464\left(\mathrm{CH}_{2}\right)$; 1337, 1266, 1238, 1158, 1136, 1033, $999(\mathrm{C}-\mathrm{O}) ; 867,810,782,729,652\left(\mathrm{CH}_{\mathrm{Ar}}\right)$. Спектр ЯМР ${ }^{1} \mathrm{H}, \delta$, м.д.: $1,15-2,25$ м [12H, $\left.\left(\mathrm{CH}_{2}\right)_{6}\right], 3,86$ с (3H, MeO), 4,49 уш. с (1H, CH), 6,76-7,49 м (3H, $\left.\mathrm{C}_{6} \mathrm{H}_{3}\right), 9,79$ с (1H, СНО). Масс-спектр: $m / z 248[M]^{+}$. Найдено, \%: С 72,83; Н 8,27, $\mathrm{C}_{15} \mathrm{H}_{20} \mathrm{O}_{3}$. Вычислено, \%: C 72,55; H 8,12, $M$ 248,32.

4-Бензилокси-3-метоксибензальдегид (VIн). Выход 79\%, т. пл. 62-63ㄷ. ИК-спектр, v, см${ }^{-1}: 3095$, 3080, 3060, 3048, 3035, $3013\left(\mathrm{CH}_{\mathrm{Ar}}\right) ; 2972,2949,2936,2870,2839\left(\mathrm{CH}_{\mathrm{Alk}}\right) ; 2762,2733\left(\mathrm{CH}_{\mathrm{CHO}}\right) ; 1694,1674$ $(\mathrm{C}=\mathrm{O}) ; 1597,1583,1505,1425,1400,1384(\mathrm{Ar}) ; 1465\left(\mathrm{CH}_{2}\right) ; 1348,1277,1261,1236,1159,1133,1031,989(\mathrm{C}-$ O); 919, 866, 856, 813, 748, 728, 698, $657\left(\mathrm{CH}_{\mathrm{Ar}}\right)$. Спектр ЯМР ${ }^{1} \mathrm{H}, \delta$, м.д.: $3,91 \mathrm{c}(3 \mathrm{H}, \mathrm{MeO}), 5,21 \mathrm{c}\left(2 \mathrm{H}, \mathrm{CH}_{2}\right)$, 6,77-7,60 м (8Н, $\mathrm{C}_{6} \mathrm{H}_{3}$ и $\left.\mathrm{C}_{6} \mathrm{H}_{5}\right), 9,81$ с (1Н, СНО). Масс-спектр: $\mathrm{m} / z 242[M]^{+}$. Найдено, \%: С 74,68; Н 6,05, $\mathrm{C}_{15} \mathrm{H}_{14} \mathrm{O}_{3}$. Вычислено, \%: С 74,36; Н 5,82, $M$ 242,27.

3,4-Диэтоксибензальдегид (VIIб). Выход $84 \%, d_{20}{ }^{20} 1,1090, n_{D}{ }^{20} 1,5555$, ИК-спектр, $v, \mathrm{~cm}^{-1}: 3079$, 3040, $3020\left(\mathrm{CH}_{\mathrm{Ar}}\right) ; 2982,2935,2901,2883,2822\left(\mathrm{CH}_{\mathrm{Alk}}\right) ; 2748,2725\left(\mathrm{CH}_{\mathrm{CHO}}\right) ; 1686(\mathrm{C}=\mathrm{O}) ; 1595,1585,1509$, 1436, 1397 (Ar); $1476\left(\mathrm{CH}_{2}\right)$; 1338, 1265, 1237, 1172, 1134, 1140 (C-O); 919, 899, 869, 807, 791, 742, 727, 655 $\left(\mathrm{CH}_{\mathrm{Ar}}\right)$. Спектр ЯМР ${ }^{1} \mathrm{H}, \delta$, м.д.: 1,30-1,62 м (6H, 2Me), 3,95-4,35 м (4H, 2 $\left.\mathrm{CH}_{2}\right), 6,88-7,52$ м (3H, $\left.\mathrm{C}_{6} \mathrm{H}_{3}\right), 9,81 \mathrm{c}$ (1Н, СНО). Масс-спектр: $m / z, 194[M]^{+}$. Найдено, \%: С 68,45; Н 7,39, $\mathrm{C}_{11} \mathrm{H}_{14} \mathrm{O}_{3}$. Вычислено, \%: С 68,02; H 7,27, $M$ 194,23.

4-изо-Пропокси-3-этоксибензальдегид (VIв). Выход $69 \%, d_{20}{ }^{20} 1,0387, n_{D}{ }^{20} 1,5445$, ИК-спектр, $v$, $\mathrm{cm}^{-1}$ : 3078, $3010\left(\mathrm{CH}_{\mathrm{Ar}}\right) ; 2980,2934,2901,2879,2820\left(\mathrm{CH}_{\mathrm{Alk}}\right) ; 2740,2727\left(\mathrm{CH}_{\mathrm{CHO}}\right) ; 1689(\mathrm{C}=\mathrm{O}) ; 1595,1582$, 1505, 1435, 1387 (Ar); $1467\left(\mathrm{CH}_{2}\right)$; 1334, 1267, 1237, 1169, 1133, 1107, 1043 (C-O); 948, 899, 869, 813, 789, $740,655\left(\mathrm{CH}_{\mathrm{Ar}}\right)$. Спектр ЯMP ${ }^{1} \mathrm{H}, \delta$, м.д.: 1,26 д $\left(6 \mathrm{H}, \mathrm{Me}_{2} \mathrm{C}\right), 1,30$ т $(3 \mathrm{H}, \mathrm{Me}), 3,99$ к $\left(2 \mathrm{H}, \mathrm{CH}_{2}\right), 4,52$ септ $(1 \mathrm{H}$, $\mathrm{CH}), 6,75-7,40$ м (3H, $\left.\mathrm{C}_{6} \mathrm{H}_{3}\right), 9,70$ с $(1 \mathrm{H}, \mathrm{CHO})$. Масс-спектр: $m / z 208[M]^{+}$. Найдено, \%: С 69,62; Н 7,88, $\mathrm{C}_{12} \mathrm{H}_{16} \mathrm{O}_{3}$. Вычислено, \%: С 69,21; Н 7,74, $M$ 208,25.

4-н-Бутокси-3-этоксибензальдегид (VIГг). Выход 84\%, т. пл. 36-37 ${ }^{\circ}$. ИК-спектр, v, см ${ }^{-1}$ : 3080, 3070, 3055, $3005\left(\mathrm{CH}_{\mathrm{Ar}}\right)$; 2988, 2967, 2955, 2918, 2870, $2848\left(\mathrm{CH}_{\mathrm{Alk}}\right) ; 2765,2740\left(\mathrm{CH}_{\mathrm{CHO}}\right) ; 1683(\mathrm{C}=\mathrm{O}) ; 1597$, 1582, 1511, 1435, 1393 (Ar); $1463\left(\mathrm{CH}_{2}\right)$; 1277, 1240, 1165, 1132, 1061, 1045, 1020, 994 (C-O); 896, 870, 820, 804, 743, $657\left(\mathrm{CH}_{\mathrm{Ar}}\right)$. Спектр ЯМР ${ }^{1} \mathrm{H}, \delta$, м.д.: 0,99 т (3H, Me), 1,46 т (3H, Me), 1,30-2,10 м [4H, $\left.\left(\mathrm{CH}_{2}\right)_{2}\right], 3,90-$ 4,32 м (4H, 2 $\left.\mathrm{CH}_{2} \mathrm{O}\right), 6,82-7,55$ м $\left(3 \mathrm{H}, \mathrm{C}_{6} \mathrm{H}_{3}\right), 9,82$ с $(1 \mathrm{H}, \mathrm{CHO})$. Масс-спектр: $m / z 222[M]^{+}$. Найдено, \%: С 70,54; Н 8,32, $\mathrm{C}_{13} \mathrm{H}_{18} \mathrm{O}_{3}$. Вычислено, \%: С 70,24; Н 8,16, $M$ 222,28.

4-изо-Бутокси-3-этоксибензальдегид (VIIд). Выход $66 \%, d_{20}{ }^{20} 0,9666, n_{D}{ }^{20} 1,5350$, ИК-спектр, $v, \mathrm{~cm}^{-}$ ': 3080, $3007\left(\mathrm{CH}_{\mathrm{Ar}}\right)$; 2972, 2961, 2932, 1918, 2875, $2820\left(\mathrm{CH}_{\mathrm{Alk}}\right)$; 2758, $2724\left(\mathrm{CH}_{\mathrm{CHO}}\right) ; 1689(\mathrm{C}=\mathrm{O}) ; 1595,1584$, 1510, 1436, 1397 (Ar); $1471\left(\mathrm{CH}_{2}\right)$; 1339, 1269, 1238, 1168, 1134, 1042, 1023, 999 (C-O); 899, 869, 809, 788, $742,653\left(\mathrm{CH}_{\mathrm{Ar}}\right)$. Спектр ЯМР ${ }^{1} \mathrm{H}, \delta$, м.д.: 1,06 д $\left(6 \mathrm{H}, \mathrm{Me}_{2} \mathrm{C}\right), 1,46$ т (3Н, Me), 1,60-2,45 м $(1 \mathrm{H}, \mathrm{CH}), 3,89$ д $\left(2 \mathrm{H}, \mathrm{CH}_{2}\right), 4,17$ к $\left(2 \mathrm{H}, \mathrm{CH}_{2}\right), 6,84-7,51$ м $\left(3 \mathrm{H}, \mathrm{C}_{6} \mathrm{H}_{3}\right), 9,83$ с (1H, CHO). Масс-спектр: $m / z 222[M]^{+}$. Найдено, $\%$ : С 70,06; Н 8,30, $\mathrm{C}_{13} \mathrm{H}_{18} \mathrm{O}_{3}$. Вычислено, \%: С 70,24; Н 8,16, $M$ 222,28.

4-изо-Амилокси-3-этоксибензальдегид (VII). Выход $71 \%, d_{20}{ }^{20} 1,0088, n_{D}{ }^{20} 1,5310$, ИК-спектр, $v$, $\mathrm{cm}^{-1}$ : 3080, $3010\left(\mathrm{CH}_{\mathrm{Ar}}\right)$; 2957, 2933, 2872, $2820\left(\mathrm{CH}_{\mathrm{Alk}}\right) ; 2765,2722\left(\mathrm{CH}_{\mathrm{CHO}}\right) ; 1689(\mathrm{C}=\mathrm{O}) ; 1595,1585,1511$, 
1436, 1396 (Ar); $1474\left(\mathrm{CH}_{2}\right) ; 1339,1267,1239,1169,1134,1043,1008,998$ (C-O); 899, 870, 812, 790, 742, 655 $\left(\mathrm{CH}_{\mathrm{Ar}}\right)$. Спектр ЯМР ${ }^{1} \mathrm{H}, \delta$, м.д.: 0,92 д (6Н, $\left.\mathrm{Me}_{2} \mathrm{C}\right), 1,44$ т $(3 \mathrm{H}, \mathrm{Me}), 1,65-2,03$ м $\left(3 \mathrm{H}, \mathrm{CH}_{2}\right.$ и $\left.\mathrm{CH}\right), 3,90-4,28$ м $\left(4 \mathrm{H}, 2 \mathrm{CH}_{2} \mathrm{O}\right), 6,75-7,48$ м $\left(3 \mathrm{H}, \mathrm{C}_{6} \mathrm{H}_{3}\right), 9,81$ с $(1 \mathrm{H}, \mathrm{CHO})$. Масс-спектр: $m / z 236[M]^{+}$. Найдено, \%: С 71,45;

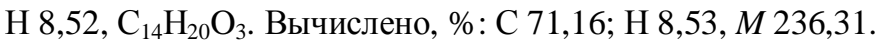

4-н-Гексилокси-3-этоксибензальдегид (VIIж). Выход $88 \%$, т. пл. $41-42^{\circ} \mathrm{C}$. ИК-спектр, $v, \mathrm{~cm}^{-1}: 3080$, $3030\left(\mathrm{CH}_{\mathrm{Ar}}\right) ; 2990,2980,2968,2955,2932,2870,2856\left(\mathrm{CH}_{\mathrm{Alk}}\right) ; 2776,2734\left(\mathrm{CH}_{\mathrm{CHO}}\right) ; 1682(\mathrm{C}=\mathrm{O}) ; 1596,1583$, 1511, 1436, 1394 (Ar); $1462\left(\mathrm{CH}_{2}\right)$; 1272, 1241, 1166, 1132, 1066, 1042, 991 (C-O); 940, 901, 867, 820, 805, 739, $660\left(\mathrm{CH}_{\mathrm{Ar}}\right)$. Спектр ЯМР ${ }^{1} \mathrm{H}, \delta$, м.д.: $0,91 \mathrm{\text {т }}(3 \mathrm{H}, \mathrm{Me}), 1,20-1,60$ м $\left[6 \mathrm{H},\left(\mathrm{CH}_{2}\right)_{3}\right], 1,47$ т $(3 \mathrm{H}, \mathrm{Me}), 1,95$ т $\left(2 \mathrm{H}, \mathrm{CH}_{2}\right), 3,90-4,40$ м $\left(4 \mathrm{H}, 2 \mathrm{CH}_{2} \mathrm{O}\right), 6,85-7,55$ м $\left(3 \mathrm{H}, \mathrm{C}_{6} \mathrm{H}_{3}\right), 9,83$ с (1H, CHO). Масс-спектр: $m / z, 250[M]^{+}$. Найдено, \%: С 72,30; Н 8,99, $\mathrm{C}_{15} \mathrm{H}_{22} \mathrm{O}_{3}$. Вычислено, \%: С 71,97; Н 8,86, $M$ 250,33.

4-н-Октилокси-3-этоксибензальдегид (VII3). Выход 85\%, т. пл. 34-35 ${ }^{\circ} \mathrm{C}$. ИК-спектр, $v, \mathrm{~cm}^{-1}: 3083$, $3005\left(\mathrm{CH}_{\mathrm{Ar}}\right) ; 2978,2946,2922,2871,2853\left(\mathrm{CH}_{\mathrm{Alk}}\right) ; 2760,2735\left(\mathrm{CH}_{\mathrm{CHо}}\right) ; 1686,1674(\mathrm{C}=\mathrm{O}) ; 1596,1584,1510$, 1437, 1395 (Ar); $1475\left(\mathrm{CH}_{2}\right)$; 1270, 1236, 1166, 1132, 1110, 1041, 1022, 997 (C-O); 896, 867, 806, 742, 730, 659 $\left(\mathrm{CH}_{\mathrm{Ar}}\right)$. Спектр ЯМР ${ }^{1} \mathrm{H}, \delta$, м.д.: 0,91 т (3H, Me), 1,18-1,66 м [10H, $\left.\left(\mathrm{CH}_{2}\right)_{5}\right], 1,48$ т (3H, Me), 1,94 т (2H, $\left.\mathrm{CH}_{2}\right)$, $3,92-4,46$ м (4H, 2 $\left.\mathrm{CH}_{2} \mathrm{O}\right), 6,80-7,58$ м (3H, $\left.\mathrm{C}_{6} \mathrm{H}_{3}\right), 9,83$ с (1H, СНО). Масс-спектр: $m / z 278[M]^{+}$. Найдено, \%: С 73,87; Н 9,71, $\mathrm{C}_{17} \mathrm{H}_{26} \mathrm{O}_{3}$. Вычислено, \%: С 73,34; Н 9,41, $M$ 278,39.

4-н-Пентадеканокси-3-этоксибензальдегид (VIи). Выход 84\%, т. пл. 36-37 ${ }^{\circ} \mathrm{C}$. ИК-спектр, $v, \mathrm{~cm}^{-1}$ : 3080, $3015\left(\mathrm{CH}_{\mathrm{Ar}}\right) ; 2979,2952,2919,2865,2849\left(\mathrm{CH}_{\mathrm{Alk}}\right) ; 2762,2733\left(\mathrm{CH}_{\mathrm{CHO}}\right) ; 1686,1673(\mathrm{C}=\mathrm{O}) ; 1595,1584$, 1509, 1437, 1401 (Ar); 1475, $1462\left(\mathrm{CH}_{2}\right)$; 1269, 1236, 1165, 1130, 1110, 1041, 1012, 997 (C-O); 898, 870, 807, $742,724,657\left(\mathrm{CH}_{\mathrm{Ar}}\right)$. Спектр ЯМР ${ }^{1} \mathrm{H}, \delta$, м.д.: 0,88 т $(3 \mathrm{H}, \mathrm{Me}), 1,26$ уш. с [24H, $\left.\left(\mathrm{CH}_{2}\right)_{12}\right], 1,48$ т $(3 \mathrm{H}, \mathrm{Me}), 1,90$ т $\left(2 \mathrm{H}, \mathrm{CH}_{2}\right), 3,90-4,30$ м $\left(4 \mathrm{H}, 2 \mathrm{CH}_{2} \mathrm{O}\right), 6,82-7,52$ м $\left(3 \mathrm{H}, \mathrm{C}_{6} \mathrm{H}_{3}\right), 9,83$ с (1H, CHO). Масс-спектр: $\mathrm{m} / z, 376[M]^{+}$. Найдено, \%: С 76,92; Н 10,68, $\mathrm{C}_{24} \mathrm{H}_{40} \mathrm{O}_{3}$. Вычислено, \%: С 76,55; Н 10,71, M 376,57.

4-Циклогексилокси-3-этоксибензальдегид (VIIк). Выход 66\%, $d_{20}{ }^{20} 1,0325, n_{D}{ }^{20} 1,5550$, ИК-спектр, $v, \mathrm{~cm}^{-1}$ : 3078, 3056, $3008\left(\mathrm{CH}_{\mathrm{Ar}}\right) ; 2979,2936,2858,2821\left(\mathrm{CH}_{\mathrm{Alk}}\right) ; 2764,2725\left(\mathrm{CH}_{\mathrm{CHO}}\right) ; 1689(\mathrm{C}=\mathrm{O}) ; 1594,1582$, 1505, 1435, 1394 (Ar); $1460\left(\mathrm{CH}_{2}\right) ; 1267,1236,1169,1134,1041,1020(\mathrm{C}-\mathrm{O}) ; 899,869,812,788,742,652$ $\left(\mathrm{CH}_{\mathrm{Ar}}\right)$. Спектр ЯMP ${ }^{1} \mathrm{H}, \delta$, м.д.: 0,95-2,25 м [10H, $\left.\left(\mathrm{CH}_{2}\right)_{5}\right], 1,43$ т $(3 \mathrm{H}, \mathrm{Me}), 4,12$ к $\left(2 \mathrm{H}, \mathrm{CH}_{2}\right), 4,37$ уш. с $(1 \mathrm{H}$, $\mathrm{CH}), 6,82-7,48$ м $\left(3 \mathrm{H}, \mathrm{C}_{6} \mathrm{H}_{3}\right), 9,81$ с $(1 \mathrm{H}, \mathrm{CHO})$. Масс-спектр: $m / z 248[M]^{+}$. Найдено, \%: С 72,89; Н 8,06, $\mathrm{C}_{15} \mathrm{H}_{20} \mathrm{O}_{3}$. Вычислено, \%: С 72,55; Н 8,12, $M$ 248,32.

4-Циклогептилокси-3-этоксибензальдегид (VIIл). Выход $74 \%, d_{20}{ }^{20} 1,0774, n_{D}{ }^{20} 1,5560$, ИК-спектр, $v, \mathrm{~cm}^{-1}:$ 3070, $3006\left(\mathrm{CH}_{\mathrm{Ar}}\right) ; 2979,2929,2859,2820\left(\mathrm{CH}_{\mathrm{Alk}}\right) ; 2765,2724\left(\mathrm{CH}_{\mathrm{CHO}}\right) ; 1688(\mathrm{C}=\mathrm{O}) ; 1594,1581,1505$, 1435, 13951394 (Ar); $1460\left(\mathrm{CH}_{2}\right)$; 1266, 1236, 1166, 1133, 1043, 995 (C-O); 900, 871, 811, 785, 743, 660 $\left(\mathrm{CH}_{\mathrm{Ar}}\right)$. Спектр ЯMР ${ }^{1} \mathrm{H}, \delta$, м.д.: 1,05-2,25 м [12H, $\left.\left(\mathrm{CH}_{2}\right)_{6}\right], 1,42$ т $(3 \mathrm{H}, \mathrm{Me}), 4,09$ к $\left(2 \mathrm{H}, \mathrm{CH}_{2}\right), 4,45$ уш. с $(1 \mathrm{H}$, $\mathrm{CH}), 6,82-7,49$ м $\left(3 \mathrm{H}, \mathrm{C}_{6} \mathrm{H}_{3}\right), 9,80$ с $(1 \mathrm{H}, \mathrm{CHO})$. Масс-спектр: $\mathrm{m} / z 248[M]^{+}$. Найдено, \%: С 72,89; Н 8,06, $\mathrm{C}_{15} \mathrm{H}_{20} \mathrm{O}_{3}$. Вычислено, \%: С 72,55; Н 8,12, $M$ 248,32.

4-Бензилокси-3-этоксибензальдегид (VIІм). Выход 88\%, т. пл. 66-67º. ИК-спектр, $v, \mathrm{~cm}^{-1}: 3081$, 3070, 3055, 3044, $\left(\mathrm{CH}_{\mathrm{Ar}}\right) ; 2976,2952,2933,2893,2879,2816\left(\mathrm{CH}_{\mathrm{Alk}}\right) ; 2762,2728\left(\mathrm{CH}_{\mathrm{CHO}}\right) ; 1686(\mathrm{C}=\mathrm{O}) ; 1596$, 1585, 1507, 1437, 1397 (Ar); 1467, $1455\left(\mathrm{CH}_{2}\right) ; 1345,1268,1227,1169,1135,1042,1014$ (C-O); 925, 897, 863, $809,742,701,654\left(\mathrm{CH}_{\mathrm{Ar}}\right)$. Спектр ЯМР ${ }^{1} \mathrm{H}, \delta$, м.д.: 1,48 т $(3 \mathrm{H}, \mathrm{Me}), 4,17$ к $\left(2 \mathrm{H}, \mathrm{CH}_{2}\right), 5,23 \mathrm{c}\left(2 \mathrm{H}, \mathrm{CH}_{2}\right), 6,85-$ 7,70 м $\left(8 \mathrm{H}, \mathrm{C}_{6} \mathrm{H}_{5}\right.$ и $\left.\mathrm{C}_{6} \mathrm{H}_{3}\right), 9,82$ с $(1 \mathrm{H}, \mathrm{CHO})$. Масс-спектр: $\mathrm{m} / z 256[M]^{+}$. Найдено, \%: С 75,14; Н 6,43, $\mathrm{C}_{16} \mathrm{H}_{16} \mathrm{O}_{3}$. Вычислено, \%: С 74,98; Н 6,29, $M$ 256,30.

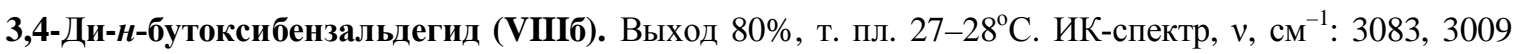
$\left(\mathrm{CH}_{\mathrm{Ar}}\right)$; 2958, 2934, $2872\left(\mathrm{CH}_{\mathrm{Alk}}\right) ; 2755,2730\left(\mathrm{CH}_{\mathrm{CHO}}\right) ; 1687,1673(\mathrm{C}=\mathrm{O}) ; 1596,1585,1510,1394$ ( $\left.\mathrm{Ar}\right) ; 1466$, $1438\left(\mathrm{CH}_{2}\right) ; 1276,1237,1167,1134,1064,1026,970(\mathrm{C}-\mathrm{O}) ; 867,807,761,740,659\left(\mathrm{CH}_{\mathrm{Ar}}\right)$. Спектр ЯМР ${ }^{1} \mathrm{H}, \delta$, м.д.: 0,96 т $(6 \mathrm{H}, 2 \mathrm{Me}), 1,12-2,08$ м [8H, $\left.2\left(\mathrm{CH}_{2}\right)_{2}\right], 3,83-4,20$ м $\left(4 \mathrm{H}, 2 \mathrm{CH}_{2} \mathrm{O}\right), 6,80-7,55$ м $\left(3 \mathrm{H}, \mathrm{C}_{6} \mathrm{H}_{3}\right), 9,80$ с (1Н, СНО). Масс-спектр: $m / z, 250[M]^{+}$. Найдено, \%: С 72,10; Н 8,76, $\mathrm{C}_{15} \mathrm{H}_{22} \mathrm{O}_{3}$. Вычислено, \%: С 71,97; Н 8,86, $M$ 250,33.

3,4-Дибензилоксибензальдегид (VIIIв). Выход 72\%, т. пл. 87-88 ${ }^{\circ} \mathrm{C}$. ИК-спектр, $v, \mathrm{~cm}^{-1}$ : 3090, 3081, 3075, 3040, 30026, $3009\left(\mathrm{CH}_{\mathrm{Ar}}\right)$; 2930, 2917, 2894, 2854, 2840, $2819\left(\mathrm{CH}_{\mathrm{Alk}}\right) ; 2762,2726\left(\mathrm{CH}_{\mathrm{CHO}}\right) ; 1676(\mathrm{C}=\mathrm{O})$; 1596, 1581, 1512, 1498, 1435, 1397, 1386 (Ar); $1453\left(\mathrm{CH}_{2}\right) ; 1282,1270,1246,1231,1165,1135,1023(\mathrm{C}-\mathrm{O})$; $860,845,821,758,736,697,660,630,590\left(\mathrm{CH}_{\mathrm{Ar}}\right)$. Спектр ЯМР ${ }^{1} \mathrm{H}, \delta$, м.д.: 5, 21 с и 5,25 с $\left(4 \mathrm{H}, 2 \mathrm{CH}_{2} \mathrm{O}\right), 6,85-$

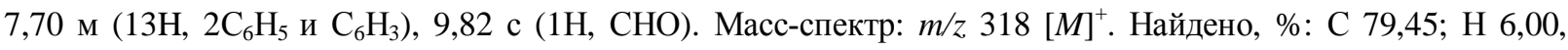
$\mathrm{C}_{21} \mathrm{H}_{18} \mathrm{O}_{3}$. Вычислено, \%: С 79,22; Н 5,70, $M$ 318,37. 


\section{Выводы}

1. Разработан удобный и масштабируемый технологический способ получения моно- и диалкоксибензальдегидов - производных природных альдегидофенолов.

2. Ряд синтезированных диалкоксибензальдегидов обладает интенсивными ароматами фруктовоягодной или цветочной направленности и являются перспективными соединениями для использования их в качестве ароматизаторов, душистых веществ и отдушек в пищевой и парфюмерной промышленности.

3. Моно- и диалкоксибензальдегиды могут служить доступными исходными соединениями для создания на их основе новых биологически активных веществ и разработки лекарственных препаратов медицинского или сельскохозяйственного назначения.

\section{Список литературы}

1. Дикусар Е.А., Выглазов О.Г., Мойсейчук К.Л., Жуковская Н.А., Козлов Н.Г. Препаративный синтез алканоатов ванилина и ванилаля // Журнал прикладной химии. 2005. Т. 78, вып. 1. С. 122-126.

2. Дикусар Е.А., Козлов Н.Г., Поткин В.И., Тлегенов Р.Т. Производные гидроксибензальдегидов ванилинового ряда: синтез, свойства и применение // Химресурс. 2010. №6. С. 39-47.

3. Дикусар Е.А., Поткин В.И., Козлов Н.Г., Тлегенов Р.Т. Функционально-замещенные производные ванилина // Весці НАН Б. Сер. хім. навук. 2011. №4. С. 105-120.

4. Першина Л.А., Ефанов М.В. Ванилин и его производные как потенциальное сырье для синтеза биологически активных соединений // Химия растительного сырья. 1997. №2. С. 42-45.

5. Дейнеко И.П. Утилизация лигнинов: достижения, проблемы и перспективы // Химия растительного сырья. 2012. №1. С. 5-20.

6. Дикусар Е.А., Козлов Н.Г., Поткин В.И., Ювченко А.П., Тлегенов Р.Т. Замещенные бензальдегиды ванилинового ряда в органическом синтезе: получение, применение, биологическая активность. Минск, 2011. 446 с.

7. Дикусар Е.А., Поткин В.И., Козлов Н.Г. Бензальдегиды ванилинового ряда. Синтез производных, применение и биологическая активность. Saarbrücken, Germany: LAP LAMBERT Academic Publishing GmbH \& Co. KG, 2012. $612 \mathrm{c}$.

8. Загоскина Н.В., Бурлакова Е.Б. Фенольные соединения: фундаментальные и прикладные аспекты. М., 2010. $400 \mathrm{c}$.

9. Кабиев О.Н., Балмуханов С.Б. Природные фенолы - перспективный класс противоопухолевых и радиопотенцирующих соединений. М., 1975. 190 с.

10. Запрометов М.Н. Основы биохимии фенольных соединений. М., 1974. 214 с.

11. Запрометов М.Н. Фенольные соединения: Распространение, метаболизм и функции в растениях. М., 1993. 272 с.

12. Рогинский В.А. Фенольные антиоксиданты: реакционная способность и эффективность. М., 1988. 247 с.

13. Барабой В.А. Биологическое действие растительных фенольных соединений. Киев, 1976. 260 с.

14. Барабой В.А. Растительные фенолы и здоровье человека. М., 1984. 155 с.

15. Барабой В.А. Биологическое действие растительных фенольных соединений. Киев, 1986. 210 с.

16. Блажей А., Шутый Л. Фенольные соединения растительного происхождения. М., 1977. 240 с.

17. Волынец А.П. Фенольные соединения в жизнедеятельности растений. Минск, 2013. 283 с.

18. Ворожцов Н.Н. Основы синтеза промежуточных продуктов и красителей. М., 1955.840 с.

19. Словарь органических соединений: строение, физические и химические свойства важнейших органических соединений и их производных / под ред. И. Хейльборн и Г.М. Бэнбери. М., 1949. Т. 1. 1072 с.; Т. 2. 982 с.; Т. $3.978 \mathrm{c}$.

20. Вацуро К.В., Мищенко Г.Л. Именные реакции в органической химии. М., 1976. 528 с.

21. Берлин А.Я. Техника лабораторной работы в органической химии. М., 1973. 368 с.

22. Дикусар Е.А., Поткин В.И., Козлов Н.Г. Функционально-замещенные производные ванилина // Пищевые добавки и современные технологии переработки сельскохозяйственного сырья : матер. докл. Всеросс. конф. СПб., 2011. С. 40-42.

23. Dikusar E.A. Functional substituted vanillin and vanillal derivatives // Renewable Wood and Plant Resources: Chemistry, Technology, Pharmacology, Medicine (RR 2011) : Book of Abstracts International Conference. St. Petersburg, 2011. Pp. 280-281.

24. Дикусар Е.А., Поткин В.И., Козлов Н.Г., Рудаков Д.А., Ювченко А.П., Тлегенов Р.Т. Продукты органического синтеза на основе лигнина - отхода целлюлозно-бумажной промышленности // Техника и технология защиты окружающей среды : материалы докл. Международн. научно-технич. конф. Минск, 2011. С. 31-35.

25. Дикусар Е.А., Выглазов О.Г., Чуйко В.А., Поткин В.И., Жуковская Н.А., Зверева Т.Д., Широкий В.Л., Лашицкая Е.В. Новые ароматизаторы, душистые вещества и отдушки на основе продуктов лесохимии // Новейшие достижения в области импортозамещения в химической промышленности и производстве строительных материалов и перспективы их развития : материалы Междун. научн.-техн. конф.: в 2 ч. Мн., 2009. Ч. 2. С. 203-206.

26. Скатецкий В.В., Дикусар Е.А., Козлов Н.Г. Синтез 4-(10,10-диметил-8-оксо-7,8,9,10,11,12-гексагидробензо[С]акридин-7-ил)-2-метокси(этокси)-фениловых эфиров, обладающих бактерицидной активностью // Новые лекарственные средства: успехи и перспективы. Уфа, 2005. С. 61-62. 
27. Dikusar E.A., Potkin V.I., Kozlov N.G., Polikarpov A.P., Shunkevich A.A. Catalytic synthesis of functional substituted 2,2-arylmethylene-bis-(3-hydroxy-5,5-dimethylcyclohex-2-enones) and 3,3,6,6-tetramethyl-9-aryl-3,4,5,6,7,9hexahydro-1H-xanthene-1,8(2H)-diones // Catalysis in Organic Synthesis (ICCOS-2012): Book of Abstracts of International Conf. Moscow, 2012. P. 156.

28. Дикусар Е.А., Поткин В.И., Клецков А.В., Козлов Н.Г., Золотарь Р.М., Чепик О.П., Ювченко А.П. Синтез и биологическая активность функционально замещенных бензальдегидов ванилинового ряда // Химические реактивы, реагенты и процессы малотоннажной химии (РЕАКТИВ-2012) : тез. докл. XXVI Междун. научнотехнич. конф. Минск, 2012. С. 86.

Поступило в редакциюю 5 апреля 2013 г.

Dikusar E.A., Potkin V.I., Petkevich C.K., Murashova M.Y., Stepin S.G., Viglazov O.G., Chuiko V.A. SYNTHESIS AND ANALYSIS MONO- AND DIALKOXY BENZALDEHYDES ODORS

${ }^{1}$ Institute of Physical Organic Chemistry, National Academy of Sciences of Belarus, Surganova st., 13, Minsk, 220072,

(Republic of Belarus),e-mail: dikusar@ifoch.bas-net.by

${ }^{2}$ Belarusian State University, Nezavisimosti ave., 4, Minsk, 220030 (Republic of Belarus)

${ }^{3}$ Vitebsk State Technological University, Moskovskii ave., 72, Vitebsk, 210035 (Republic of Belarus)

${ }^{4}$ Ltd. «Teresa Inter», Olimpiiskii ave., 22, Moscow, 129110 (Russia)

A convenient and scalable technological method of mono- and dialkoxy benzaldehydes synthesis for their further use as aromatic compounds and starting materials for further chemical modifications and conversions.

Keywords: benzaldehydes of vanniline row, phenols, bromalkany, Williamson reaction, analysis of odors, aromatic compounds.

\section{References}

1. Dikusar E.A., Vyglazov O.G., Moiseichuk K.L., Zhukovskaia N.A., Kozlov N.G. Zhurnal prikladnoi khimii, 2005, vol. 78, no. 1, pp. 122-126. (in Russ.).

2. Dikusar E.A., Kozlov N.G., Potkin V.I., Tlegenov R.T. Khimresurs, 2010, no. 6, pp. 39-47. (in Russ.).

3. Dikusar E.A., Potkin V.I., Kozlov N.G., Tlegenov R.T. Vesci NAN B. Ser. him. navuk, 2011, no.4, pp. 105-120. (in Russ.).

4. Pershina L.A., Efanov M.V. Khimiia rastitel'nogo syr'ia, 1997, no. 2, pp. 42-45. (in Russ.).

5. Deineko I.P. Khimiia rastitel'nogo syr'ia, 2012, no. 1, pp. 5-20. (in Russ.).

\footnotetext{
* Corresponding author.
} 
6. Dikusar E.A., Kozlov N.G., Potkin V.I., Iuvchenko A.P., Tlegenov R.T. Zameshchennye benzal'degidy vanilinovogo riada $v$ organicheskom sinteze: poluchenie, primenenie, biologicheskaia aktivnost'. [Substituted benzaldehydes vanillyl series in organic synthesis: preparation, use, biological activity]. Minsk, 2011, 446 p. (in Russ.).

7. Dikusar E.A., Potkin V.I., Kozlov N.G. Benzal'degidy vanilinovogo riada. Sintez proizvodnykh, primenenie i biologicheskaia aktivnost'. [Benzaldehydes vanillyl series. Synthesis of applying and biological activity]. Saarbrücken, Germany: LAP LAMBERT Academic Publishing GmbH \& Co. KG, 2012, 612 p. (in Russ.).

8. Zagoskina N.V., Burlakova E.B. Fenol'nye soedineniia: fundamental'nye i prikladnye aspekty. [Phenolic compounds: fundamental and applied aspects]. Moscow, 2010, 400 p. (in Russ.).

9. Kabiev O.N., Balmukhanov S.B. Prirodnye fenoly - perspektivnyi klass protivoopukholevykh $i$ radiopotentsiruiushchikh soedinenii. [Natural phenols - a promising class of anticancer compounds and radiopotentsiruyuschih]. Moscow, 1975, 190 p. (in Russ.).

10. Zaprometov M.N. Osnovy biokhimii fenol'nykh soedinenii. [Fundamentals of Biochemistry of phenolic compounds]. Moscow, 1974, 214 p. (in Russ.).

11. Zaprometov M.N. Fenol'nye soedineniia: Rasprostranenie, metabolizm i funktsii v rasteniiakh. [Phenolic compounds: Distribution, metabolism and function in plants]. Moscow, 1993, 272 p. (in Russ.).

12. Roginskii V.A. Fenol'nye antioksidanty: reaktsionnaia sposobnost' $i$ effektivnost'. [Phenolic antioxidants: reactivity and efficiency]. Moscow, 1988, 247 p. (in Russ.).

13. Baraboi V.A. Biologicheskoe deistvie rastitel'nykh fenol'nykh soedinenii. [The biological effect of plant phenolic compounds]. Kiev, 1976, 260 p. (in Russ.).

14. Baraboi V.A. Rastitel'nye fenoly i zdorov'e cheloveka. [Plant phenolics and human health]. Moscow, 1984,155 p. (in Russ.).

15. Baraboi V.A. Biologicheskoe deistvie rastitel'nykh fenol'nykh soedinenii. [The biological effect of plant phenolic compounds]. Kiev, 1986, 210 p. (in Russ.).

16. Blazhei A., Shutyi L. Fenol'nye soedineniia rastitel'nogo proiskhozhdeniia. [Phenolic compounds of plant origin]. Moscow, 1977, 240 p. (in Russ.).

17. Volynets A.P. Fenol'nye soedineniia v zhiznedeiatel'nosti rastenii. [Phenolic compounds in plant life]. Minsk, 2013, 283 p. (in Russ.).

18. Vorozhtsov N.N. Osnovy sinteza promezhutochnykh produktov i krasitelei. [Principles of the synthesis of intermediates and dyes]. Moscow, 1955, 840 p. (in Russ.).

19. Slovar' organicheskikh soedinenii: stroenie, fizicheskie i khimicheskie svoistva vazhneishikh organicheskikh soedinenii i ikh proizvodnykh. [Dictionary of organic compounds: structure, physical and chemical properties of important organic compounds and their prizvodnyh]. Ed. I. Kheil'born and G.M. Benberi. Moscow, 1949, vol. 1, 1072 p.; vol. 2 , 982 p.; vol. 3, 978 p. (in Russ.).

20. Vatsuro K.V., Mishchenko G.L. Imennye reaktsii v organicheskoi khimii. [Named Reactions in Organic Chemistry]. Moscow, 1976, 528 p. (in Russ.).

21. Berlin A.Ia. Tekhnika laboratornoi raboty v organicheskoi khimii. [Technique laboratory work in organic chemistry]. Moscow, 1973, 368 p. (in Russ.).

22. Dikusar E.A., Potkin V.I., Kozlov N.G. Pishchevye dobavki i sovremennye tekhnologii pererabotki sel'skokhoziaistvennogo syr'ia: mater. dokl. vseross. konf. [Food additives and modern technologies of processing of agricultural raw materials: materials national conference]. St. Petersburg, 2011, pp. 40-42. (in Russ.).

23. Dikusar E.A. Renewable Wood and Plant Resources: Chemistry, Technology, Pharmacology, Medicine (RR 2011) : Book of Abstracts International Conference, St. Petersburg, 2011, pp. 280-281.

24. Dikusar E.A., Potkin V.I., Kozlov N.G., Rudakov D.A., Iuvchenko A.P., Tlegenov R.T. Tekhnika i tekhnologiia zashchity okruzhaiushchei sredy: materialy dokl. mezhdunarodn. nauchno-tekhnich. konf. [Engineering and Technology of the Environment: Proceedings of the International Scientific and Technical Conference]. Minsk, 2011, pp. 31-35. (in Russ.).

25. Dikusar E.A., Vyglazov O.G., Chuiko V.A., Potkin V.I., Zhukovskaia N.A., Zvereva T.D., Shirokii V.L., Lashitskaia E.V. Noveishie dostizheniia $v$ oblasti importozameshcheniia $v$ khimicheskoi promyshlennosti i proizvodstve stroitel'nykh materialov i perspektivy ikh razvitiia: materialy mezhdunar. nauchn.tekhn. konf. [The latest achievements in the field of import substitution in the chemical industry and the production of building materials and their development prospects: Proceedings of the International Scientific and Technical Conference]. Minsk, 2009, part. 2, pp. 203-206. (in Russ.).

26. Skatetskii, V.V., Dikusar E.A., Kozlov N.G. Novye lekarstvennye sredstva: uspekhi i perspektivy. [New medicines: progress and prospects]. Ufa, 2005, pp. 61-62. (in Russ.).

27. Dikusar E.A., Potkin V.I., Kozlov N.G., Polikarpov A.P., Shunkevich A.A. Catalysis in Organic Synthesis (ICCOS2012): Book of Abstracts of International Conf., Moscow, 2012, p. 156.

28. Dikusar E.A., Potkin V.I., Kletskov A.V., Kozlov N.G., Zolotar' R.M., Chepik O.P., Iuvchenko A.P. Khimicheskie reaktivy, reagenty i protsessy malotonnazhnoi khimii (REAKTIV-2012): tez. dokl. XXVI mezhdunar. nauchnotekhnich. konf. [Chemical reagents and fine chemical processes (REACT-2012): tezizy reports XXVI International Scientific and Technical Conference]. Minsk, 2012, p. 86. (in Russ.). 